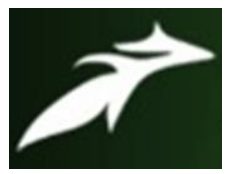

N.I Suleiman, International Journal of Advances in Agricultural Science and Technology,

Vol.8 Issue.2, February-2021, pg. 62-70

ISSN: 2348-1358

Impact Factor: 6.057

NAAS Rating: 3.77

\title{
IMPACT OF BIOPHYSICAL CONDITIONS ON THE YIELD OF LEGUMES AND VARIETAL RESPONSE TO INPUT OF GROUNDNUT VARIETY (SAMNUT 24) IN AJINGI AND GAYA SAVANNA ZONE OF NIGERIA
}

\author{
N.I Suleiman \\ (PhD Candidate) Department of Crop Science \\ Kano University of Science and Technology, Wudil \\ Kano State Nigeria \\ E-mail: nuradogodawaki@gmail.com \\ $+2348038762892$ \\ DOI: 10.47856/ijaast.2021.v08i2.009
}

\begin{abstract}
Field experiments were conducted at Ajingi and Gaya operational areas of N2Africa both in Kano State, Nigeria for the impact of biophysical conditions on the yield of legumes and varietal response to input of groundnut variety (samnut 24) in Ajingi and Gaya savanna zone of Nigeria. The experiment comprised six (6) treatments, groundnut seeds Samnut 24 have been planted in each plot. Four (4) of the plots had received P fertilizer at the rate of $30 \mathrm{~kg} \mathrm{P}_{2}{ }^{0} 5 / \mathrm{ha}$ (Single Super Phosphate SSP), three (3) plots had received $\mathrm{K}$ in form of MOP at the rate of $20 \mathrm{~kg} \mathrm{~K}_{2} 0 / \mathrm{ha}$ while two (2) plots each had received micronutrients and organic manure. The remaining one plot had serve as control no input. The treatments were laid out in a Randomized Complete Block Design (RCBD) with five replications. Application of all rates and combination of different of fertilizer produced statistically similar treatments effect per plot at both locations and combined. However, the study indicated that, application of combination of PK-MN-OM and PK-MN alone were statistically superior in Plant height, Number of branches, Canopy spread, Number of plant established and Days to maturity. There were statistically significant higher positive correlations between growth and yield components at both locations. Conclusively, the results of the study showed that, application of PK-MN-OM and PK-MN respectively were statistically superior to PK, P, OM and the control treatment. It is hereby recommended that, application of PKMN-OM and PK-MN should be adopted and phosphorus fertilizer at the rate of $30 \mathrm{~kg} / \mathrm{ha}$, potassium $20 \mathrm{~kg} / \mathrm{ha}$ and $40 \mathrm{~kg} / \mathrm{ha}$ of organic manure.
\end{abstract}

Keywords: Biophysical condition; Varietal response to input; Groundnut; Yield; Samnut 24

\section{INTRODUCTION}

Groundnut (Arachis hypogaea L.) of the family leguminasea, is an annual legume which bears many names including peanut, earthnut, monkey-nut and goobers. It originated from Latin America and the Portuguese introduced it into African continent from Brazil in the $16^{\text {th }}$ century (Adinya et al.., 2010; Hamidu el al., 2007). The crop is mainly grown for oilseed, food and animal feed (Pande et al... 2003; Upadhyaya et al.., 2006). It is the world $13^{\text {th }}$ most important food crop, $4^{\text {th }}$ most important source of edible oil and 3th most important vegetable protein (Taru et al., 2010). Groundnut seeds known as kernels contain $40-50 \%$ fats, $20-50 \%$ protein and $10-20 \%$ 


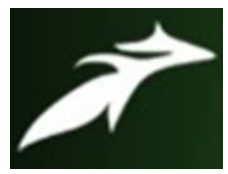

N.I Suleiman, International Journal of Advances in Agricultural Science and Technology, Vol.8 Issue.2, February-2021, pg. 62-70

ISSN: 2348-1358

Impact Factor: 6.057

NAAS Rating: 3.77

carbohydrates (Sorrensen et al., 2004). They are a nutritional source of vitamin E and other minerals for human health including niacin, falacin, calcium, phosphorus magnesium, zinc, iron, riboflavin, thiamine and potassium. Groundnut is useful in the treatment of hemophilia, and can cure stomatitis, prevent diarrhea and is beneficial for growing children and for both pregnant and nursing mothers (Akobundu, 1998). Kernels are consumed directly as raw, roasted or boiled nuts and vines are used as fodder for cattle (Pompeu, 1980; Hong et al., 1994). The crop is used as industrial materials for producing oil cakes and fertilizer, extracted oil from kernel is used as culinary oil and other crop extracts are used as animal feeds (Nigan, and Lenne, 1996). Almost each part of the crop is used in some ways. These multiple uses of groundnuts plant make it important for both food and cash crop for the available domestic, or worldwide external markets in several developing and developed countries. Globally, 50\% of the crop is used for oil extraction, $37 \%$ for confectionary use and 12\% seeds purpose (Teru et al., 2010). Groundnuts are grown in nearly 100 countries worldwide. China, India, Nigeria, USA, Indonesia Senegal and Sudan are major producers growing an estimated total area of 21.8 million ha (Taru et al., 2010). In Nigeria, the crop is presently grown throughout the country with the exception of the riverine and swampy areas. Groundnut is either cultivated sole or in mixture with other crops like Mize, Sorghum, Millet or Cassava. Fifty percent of the groundnuts produced in Nigeria are in mixtures (Anonymous, 2004). Developing countries accounts for $96 \%$ of the global production. Asia accounts for 58\% of the global groundnuts area and $67 \%$ of the groundnuts production with annuals growth rate of $1.28 \%$ for area, $2 \%$ for production $0.71 \%$ of productivity. Twenty five countries in Asia produce $71.7 \%$ of the crop while, 46 countries in Africa produce $18.6 \%$ of the total produce. North-Central America produces $7.5 \%$ from a small area of $3.7 \%$ of the overall estimated global area of producers. Groundnut is a crop which can be grown in the tropics and warm temperate region between $40^{\circ} \mathrm{N}$ and $40^{\circ} \mathrm{S}$ latitude (Roman, 2001). The crop has some specific environmental and management requirements which must to be met the closet possible in order to achieve a good crop yield. Some of the climatic requirements for groundnut crop production include rainfall of between $450 \mathrm{~mm}-1250$ per annum which should be well distributed and on an altitude of no more than $1500 \mathrm{~m}$ (Busolo et al., 2002) or an irrigation application of about $500 \mathrm{~mm}-600 \mathrm{~mm}$ per its production season, a temperature range of $20^{\circ} \mathrm{C}$ $-35^{\circ} \mathrm{C}$, lots of sunshine and optimum relative humidity up to its maturity are among the requirements.

\section{MATERIALS AND METHODS}

\section{Experimental Sites}

The study was conducted during 2015 wet season in two locations operational areas of N2Africa. Location 1: Gaya (Latitude $11^{\circ} .762238 \mathrm{~N}$ and longitude $008^{\circ}$. 95753E; Alt. 432mabove sea level). Location 2: Ajingi (Latitude $11^{0}$. $97570 \mathrm{~N}$ and Longitude $009^{\circ}$. 04805E; Alt. $417 \mathrm{~m}$ above sea level). Both sites are located in the Sudan Savanna agroecological zone.

\section{Collection and Analysis of Soil Sample}

Soil sample were taken at random from each of the two sites before planting at $0-25 \mathrm{~cm}$ depth using soil auger. Composite soil sample were made for each site and were air-dried, sieve using $2 \mathrm{~mm}$ mesh and analyzed for physical and chemical properties using standard procedures. The $\mathrm{pH}$ was determined by glass electrode $\mathrm{pH}$ Meter; particles size; Organic carbon by oxidation; Available phosphorus; Total Nitrogen content; Exchangeable Bases (Ca, $\mathrm{Mg}, \mathrm{K}$, and Na); Cation Exchange Capacity. (Bremner and Mulvaney, 1982) 


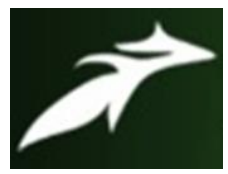

N.I Suleiman, International Journal of Advances in Agricultural Science and Technology,

Vol.8 Issue.2, February-2021, pg. 62-70

ISSN: 2348-1358

Impact Factor: 6.057

NAAS Rating: 3.77

\section{Treatment and Experimental Design}

In each site the experiment comprised of six treatments in the field layout, groundnut seed Samnut 24 have been planted in each plot. Four 4 plots received phosphorus $\mathrm{P}$ fertilizer at the recommended rate of $30 \mathrm{~kg} \mathrm{p}_{2}{ }^{0} 5 / \mathrm{ha}$ (Single Super Phosphate SSP). Three 3 plots received potassium K in form of MOP at the recommended rate of 20kg $\mathrm{K}_{2} \mathrm{O} / \mathrm{h}$. Two 2 plots received micronutrient 33 grams of agrolyzer and dissolve in 10litre of water which had been applied to $10 \times 10 \mathrm{~m}$ plot. Organic manure application 4 tons that is $40 \mathrm{~kg}$ per plot of $100^{2}$, one plot saved as control. All the treatments were laid out in randomized complete block design (RCBD) with five replications.

\section{Land preparation}

The land was cleared and ridged by using ox-plough and it was ridged against slope, the plot of 10x10m was established appropriately. Alley of $0.5 \mathrm{~m}$ spacing between rows $/$ ridge is $75 \mathrm{~cm}$

\section{Sowing}

Groundnut seed was sown at the rate Of 2 seeds per hole without thinning, spacing between plant stand $10 \mathrm{~cm}$ and $75 \mathrm{~cm}$ intra raw spacing.

\section{Fertilizer application}

In each plot, four plots of $10 \mathrm{mx} 10 \mathrm{~m}$ were fertilized by applying $0.3 \mathrm{~kg} \mathrm{P}_{2}{ }^{0} 5$ which is equal to $2 \mathrm{~kg} \mathrm{SSP} / \mathrm{plot}$ of $100 \mathrm{~m}^{2}$. Phosphorus fertilizer (SSP) were applied at planting by dibbled the fertilizer and covered. Potassium $\mathrm{K}$ was applied to three plots of $10 \mathrm{mx} 10 \mathrm{~m}$ at the rate of $\mathrm{K}_{2} 0$ in form of MOP which is translated into $0.33 \mathrm{~kg} \mathrm{~K} 20 / \mathrm{plot}$ of $100^{2} \mathrm{~m}$. Recommended rate of organic manure $40 \mathrm{~kg} / \mathrm{ha}$ were applied to plot of $100^{2} \mathrm{~m}, 33$ grams of micronutrients agrolyzer were applied to two plots of $10 \mathrm{mx} 10 \mathrm{~m}$.

\section{Harvesting}

Harvesting was done when the foliage slightly turned yellow and the pods attained physiological maturity. The plant was then cut below the level of the pods in the soil with hoe.

\section{Data collection}

Plant height: five pant per plot were randomly selected and tagged from the sampling rows, their height were measured from the base of the plant to the end of the terminal bud using meter ruler at 3,6,9, and 12 WAS, and average mean was recorded.

\section{Number of branches:}

The numbers of branches per plants at 3,6, 9, and 12 WAS, and average mean was recorded.

\section{Canopy spread:}

five plants per plot were randomly selected and tagged from the sampling rows, their spread were measured by the use of meter ruler at 3,6,9, and 12 WAS and begin from the base of the plant to the end of terminal bug spread, and average spread was computed and recorded.

\section{Number of plant established:}

The number of plant established was assessed by counting the stand in each of the plot and recorded. 


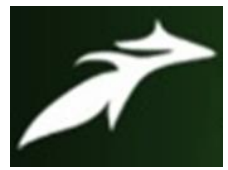

N.I Suleiman, International Journal of Advances in Agricultural Science and Technology,

Vol.8 Issue.2, February-2021, pg. 62-70

ISSN: 2348-1358

Impact Factor: 6.057

NAAS Rating: 3.77

\section{Days to maturity:}

The number of days where $80 \%$ of the plants in each plots reach maturity was $90-110$ days after sowing were recorded.

\section{Data Analysis}

The data was analyzed using SAS latest version (2010), the data collected was subjected to Analysis of Variance (ANOVA), as described by Snedecor and Cochran (1976) and treatment means were compared using Duncan Multiple Range Test (DMRT) Duncan, 1955.

\section{RESULT AND DISCUSSION}

\section{Physiochemical Properties of the Soil at Experimental Sites:}

The characteristics of the soil at experimental sites are presented in Table 1. The soil at Ajingi was sandy loam while that of Gaya was loamy sandy in texture. The $\mathrm{pH}$ value for Ajingi was 6.68 and that of Gaya was 5.83 which indicate there are different reactions. Soil had medium organic carbon $0.392 \mathrm{gkg}_{-}{ }^{1}$ for Ajingi and Gaya $0.757 \mathrm{gkg}_{-}{ }^{1}$ respectively, the total Nitrogen content for Ajingi $0.22 \mathrm{gkg}^{-1}$ and $0.42 \mathrm{gkg}^{-1}$ for Gaya which was very low, the available phosphorus content of Ajingi was high $11.25\left(\mathrm{mgKg}^{-1}\right)$. The exchangeable cations $(\mathrm{Ca}, \mathrm{Mg})$ at Ajingi $\mathrm{Ca}$ was 3.86 and that of Gaya was $2.91, \mathrm{Mg}$ at Ajingi was 2.30 , Gaya was at $1.50 \mathrm{~K}$ potassium was medium at both location range between $0.18-0.12$, Na content of both locations was moderate. The CEC of the soil analysis from both locations were medium and ranged between $5.89 \mathrm{cmol}^{+} \mathrm{Kgha}^{-1}$ for Ajingi and $4.21 \mathrm{cmol}^{+} \mathrm{Kgha}^{-1}$ for Gaya soil.

Table 1: Soil characteristics of the experimental sites at Ajingi and Gaya $(0-25 \mathrm{~cm}$ depth)

\begin{tabular}{lcc}
\hline \multicolumn{1}{c}{ Soil Properties } & Ajingi & Gaya \\
\hline Particle size $(\%)$ & & \\
Sandy & 89.9 & 80 \\
Clay & 3 & 4 \\
Silt & 7.1 & 10 \\
Texture Class & Sandy loam & Loam sandy \\
Chemical Properties & & \\
pH in water $(1: 2: 5)$ & 6.68 & 5.83 \\
Organic carbon $\left(\mathrm{gkg}^{-1}\right)$ & 0.392 & 0.757 \\
Total Nitrogen $\left(\mathrm{gkg}^{-1}\right)$ & 0.22 & 0.42 \\
Available P $\left(\mathrm{mg}^{-1} \mathrm{~kg}^{-1}\right)$ & 11.25 & 3.92 \\
Exchangeable base $(\mathbf{c m o} / \mathbf{k g})$ & & \\
Ca & 3.86 & 2.91 \\
Mg & 2.30 & 1.50 \\
$\mathrm{~K}$ & 0.18 & 0.12 \\
$\mathrm{Na}$ & 0.54 & 0.22 \\
$\mathrm{CEC}$ & 5.89 & 4.21 \\
\hline
\end{tabular}




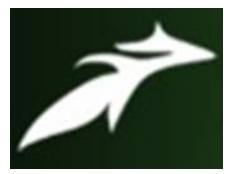

N.I Suleiman, International Journal of Advances in Agricultural Science and Technology,

Vol.8 Issue.2, February-2021, pg. 62-70

ISSN: 2348-1358

Impact Factor: 6.057

NAAS Rating: 3.77

\section{Plant Height}

Impact of biophysical conditions on the yield of legumes and varietal response to input of groundnut variety on plant height is presented in table 2. Application of all rates and combination of different of fertilizer produced statistically $(\mathrm{P} \leq 0.05)$ similar plant height per plant, irrespective of locations and various sampling period, except at 6 WAS and at Ajingi site where by application of combination of PK-MN-OM produced statistically similar plant height compared with application of PK and P alone, though it was statistically similar at par with OM, PK_mn and the control treatment.

Table 2: Impact Of biophysical condition on the yield of legumes and varietal response to input of Groundnut Variety on Plant Height at 3, 6, 9 and 12 WAS at Ajingi and Gaya.

\begin{tabular}{|c|c|c|c|c|c|c|c|c|}
\hline Treatment & Ajingi & & & WAS & & & Gaya & \\
\hline & 3 & 6 & 9 & 12 & 3 & 6 & 9 & 12 \\
\hline PK-MN-OM & 6.00 & 20.31ab & 41.56 & 57.16 & 8.36 & 30.97 & 49.06 & 60.56 \\
\hline OM & 5.10 & $18.43 b$ & 41.33 & 56.80 & 7.46 & 29.52 & 44.76 & 57.80 \\
\hline PK & 6.18 & $19.7 \mathrm{ab}$ & 40.15 & 56.56 & 7.37 & 27.39 & 47.65 & 60.56 \\
\hline $\mathrm{P}$ & 6.14 & $21.44 \mathrm{a}$ & 39.67 & 56.52 & 7.27 & 25.77 & 40.60 & 55.97 \\
\hline PK-MN & 5.94 & $17.91 \mathrm{~b}$ & 41.97 & 57.05 & 7.59 & 28.67 & 44.07 & 57.80 \\
\hline CONTROL & 6.24 & $17.54 \mathrm{~b}$ & 38.14 & 57.73 & 7.35 & 26.43 & 46.28 & 59.06 \\
\hline $\mathrm{SE} \pm$ & 0.37 & 0.85 & 1.64 & 0.59 & 0.39 & 1.84 & 2.41 & 1.57 \\
\hline Significance & NS & $*$ & NS & NS & NS & NS & NS & NS \\
\hline \multicolumn{9}{|l|}{ Interaction } \\
\hline $\mathrm{T} \times \mathrm{E}$ & NS & NS & NS & NS & NS & NS & NS & NS \\
\hline
\end{tabular}

Keyword: Means within a column followed by same letter(s) are statistically similar $(\mathrm{P} \leq 0.05)$ using Duncan Multiple Range Test $($ DMRT); NS = Not Significance; PK-MN = Phosphorus + Potassium + Micronutrient; OM = Organic Manure; PK-MN-OM = Phosphorus + Potassium + Micronutrient + Organic Manure; PK = Phosphorus + Potassium; $\mathrm{CONTROL}=$ No input; $\mathrm{P}=$ Phosphorus only; $\mathrm{T}=$ Treatment; $\mathrm{E}=$ Experiment; $* *=$ significant at $1 \%$ Probability; WAS $=$ Weeks After Sowing.

\section{Number of Branches}

Impact of biophysical conditions on the yield of legumes and varietal response to input of groundnut variety on number of branches is presented in table 3. Application of all rates combination of different of fertilizer produced statistically $(\mathrm{P} \leq 0.05)$ similar number of branches per plot, irrespective of locations and the various sampling period except at 9 WAS and at Ajingi site. At 9 WAS and at Ajingi site the various types of fertilizer applied produced statistically similar number of branches, except that the application of PK-MN-OM produced significantly more number of branches than plots fertilized with only OM. 


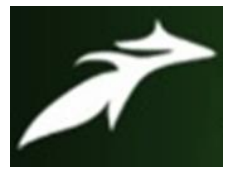

N.I Suleiman, International Journal of Advances in Agricultural Science and Technology,

Vol.8 Issue.2, February-2021, pg. 62-70

ISSN: 2348-1358

Impact Factor: 6.057

NAAS Rating: 3.77

Table 3: Impact Of biophysical condition on the yield of legumes and varietal response to input of Groundnut Variety on Number of Branches at 3, 6, 9 and 12 WAS at Ajingi and Gaya.

\begin{tabular}{|c|c|c|c|c|c|c|c|c|}
\hline Treatment & Ajingi & & & WAS & & & Gaya & \\
\hline & 3 & 6 & 9 & 12 & 3 & 6 & 9 & 12 \\
\hline PK-MN-OM & 4.60 & 5.96 & $9.92 \mathrm{a}$ & 9.96 & 4.80 & 6.00 & $9.24 \mathrm{a}$ & 9.24 \\
\hline $\mathrm{OM}$ & 4.36 & 5.64 & $8.92 b$ & 9.56 & 4.68 & 6.04 & $8.48 \mathrm{a}$ & 8.48 \\
\hline PK & 4.32 & 5.92 & $9.08 \mathrm{ab}$ & 9.08 & 4.60 & 6.32 & $9.04 \mathrm{a}$ & 9.06 \\
\hline $\mathrm{P}$ & 4.48 & 6.00 & $9.28 \mathrm{ab}$ & 9.28 & 4.76 & 5.88 & $8.76 \mathrm{a}$ & 8.84 \\
\hline PK-MN & 4.68 & 5.92 & $9.36 \mathrm{ab}$ & 9.36 & 4.72 & 5.88 & $8.56 a$ & 8.56 \\
\hline CONTROL & 4.72 & 5.96 & $9.04 \mathrm{ab}$ & 9.08 & 4.72 & 5.88 & $9.02 \mathrm{a}$ & 9.00 \\
\hline $\begin{array}{l}\mathrm{SE} \pm \\
\text { Significance } \\
\text { Interaction }\end{array}$ & NS & NS & $*$ & NS & NS & NS & NS & NS \\
\hline T x E & NS & NS & NS & NS & NS & NS & NS & NS \\
\hline
\end{tabular}

Keyword: Means within a column followed by same letter(s) are statistically similar $(\mathrm{P} \leq 0.05)$ using Duncan Multiple Range Test (DMRT); NS = Not Significance; PK-MN = Phosphorus + Potassium + Micronutrient; OM = Organic Manure; PK-MN-OM = Phosphorus + Potassium + Micronutrient + Organic Manure; PK = Phosphorus + Potassium; CONTROL $=$ No input; $\mathrm{P}=$ Phosphorus only; $\mathrm{T}=$ Treatment; $\mathrm{E}=$ Experiment; $* *=$ significant at $1 \%$ Probability; WAS= Weeks After Sowing.

\section{Canopy Spread}

Impact of biophysical conditions on the yield of legumes and varietal response to input of groundnut variety on canopy spread is presented in table 4. Application of all rates and combination of different of fertilizer produced statistically $(\mathrm{P} \leq 0.05)$ similar canopy spread per plot, irrespective of locations and the sampling period, except 3 and 6 WAS under Gaya locations respectively. Application of various types of fertilizer produced statistically $(\mathrm{P} \leq 0.01)$ similar canopy spread per plot and the control treatment, though application of PK-MN-OM as well as application of $\mathrm{OM}$ alone were statistically superior compared to the application of PK alone. At 6 WAS under same Ajingi site, application of PK-MN-OM produced significant more canopy spread than all other fertilizer combinations, which were statistically at par with each other. At 3 WAS under Gaya location, similar trend to Ajingi 6 WAS recorded was observed, though application of PK-MN-OM, OM alone and PK were statistically at par.

Table 4: Impact Of biophysical condition on the yield of legumes and varietal response to input of Groundnut Variety on Canopy spread at 3, 6,9 and 12 WAS at Ajingi and Gaya.

\begin{tabular}{lcccccccc}
\hline Treatment & Ajingi & & \multicolumn{3}{c}{ WAS } & \multicolumn{3}{c}{ Gaya } \\
\hline & 3 & 6 & 9 & 12 & 3 & 6 & 9 & 12 \\
\hline PK-MN-OM & $224.22 \mathrm{a}$ & $774.53 \mathrm{a}$ & 3064.8 & 2989.0 & $330.53 \mathrm{a}$ & 1260.4 & 2335.6 & 3434.9 \\
OM & $215.91 \mathrm{a}$ & $637.19 \mathrm{~b}$ & 3981.1 & 3054.9 & $290.43 \mathrm{ab}$ & 1293.5 & 2180.7 & 3189.6 \\
PK & $170.5 \mathrm{~b}$ & $654.86 \mathrm{~b}$ & 2984.7 & 3105.5 & $302.69 \mathrm{ab}$ & 1125.2 & 2300.9 & 3480.2 \\
P & $205.40 \mathrm{ab}$ & $558.18 \mathrm{~b}$ & 2795.4 & 2987.2 & $243.44 \mathrm{~b}$ & 1207.5 & 2277.7 & 3246.4
\end{tabular}




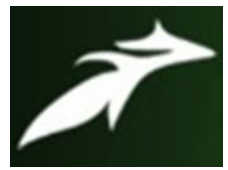

N.I Suleiman, International Journal of Advances in Agricultural Science and Technology, Vol.8 Issue.2, February-2021, pg. 62-70

ISSN: 2348-1358

Impact Factor: 6.057

NAAS Rating: 3.77

\begin{tabular}{lcccccccc} 
PK-MN & $200.72 \mathrm{ab}$ & $566.92 \mathrm{~b}$ & 2504.7 & 2887.8 & $262.92 \mathrm{~b}$ & 1204.4 & 2243.4 & 3298.0 \\
CONTROL & $202.04 \mathrm{ab}$ & $624.17 \mathrm{~b}$ & 3001.2 & 2881.5 & $266.64 \mathrm{~b}$ & 1008.3 & 2420.1 & 3311.9 \\
SE \pm & 11.88 & 38.8 & 476.3 & 166.9 & 19.9 & 105.9 & 103.4 & 102.9 \\
Significance & $*$ & $* *$ & NS & NS & $*$ & NS & NS & NS \\
Interaction & & & & & & & & \\
T x E & NS & NS & NS & NS & NS & NS & NS & NS \\
\hline
\end{tabular}

Keyword: Means within a column followed by same letter(s) are statistically similar $(\mathrm{P} \leq 0.05)$ using Duncan Multiple Range Test $($ DMRT); NS = Not Significance; PK-MN = Phosphorus + Potassium + Micronutrient; OM = Organic Manure; PK-MN-OM = Phosphorus + Potassium + Micronutrient + Organic Manure; PK = Phosphorus + Potassium; CONTROL $=$ No input; $\mathrm{P}=$ Phosphorus only; $\mathrm{T}=$ Treatment; $\mathrm{E}=$ Experiment; $* *=$ significant at $1 \%$ Probability; WAS= Weeks After Sowing.

\section{Number of Plants Established}

Impact of biophysical conditions on the yield of legumes and varietal response to input of groundnut variety on number of plant established is presented in table 5. Application of all rates and combination of different of fertilizer produced statistically $(\mathrm{P} \leq 0.01)$ similar number of plants established per plot, irrespective of locations and the combined analysis. However, the various types of fertilizer applied produced significantly higher number of established plants per plot than the control treatment in all locations and in the combined analysis. Application of $\mathrm{OM}$ or PK and P or PK-MN alone produced statistically similar but the least number of established plants compared to the application of PK-MN-OM which were statistically at par but statistically superior to the application of OM or $\mathrm{PK}$ and $\mathrm{P}$ or PK-MN alone and control treatment that produced less number of plants established. There was statistically significant treatments effect recorded at both locations and combined analysis.

\section{Table 5: Impact Of biophysical condition on the yield of legumes and varietal response to input of Groundnut Variety on Number of plants established at Ajingi and Gaya and combined.}

\begin{tabular}{lccc}
\hline Treatment & Ajingi & Gaya & Combined \\
\hline PK-MN-OM & $1570.8 \mathrm{a}$ & $1285.0 \mathrm{a}$ & $1427.9 \mathrm{a}$ \\
OM & $1432.6 \mathrm{a}$ & $1241.0 \mathrm{a}$ & $1336.5 \mathrm{a}$ \\
PK & $1414.6 \mathrm{a}$ & $1221.0 \mathrm{a}$ & $1317.8 \mathrm{a}$ \\
$\mathrm{P}$ & $1388.6 \mathrm{a}$ & $1252.4 \mathrm{a}$ & $1320.5 \mathrm{a}$ \\
PK-MN & $1373.2 \mathrm{a}$ & $1296.2 \mathrm{a}$ & $1334.7 \mathrm{a}$ \\
CONTROL & $865.2 \mathrm{~b}$ & $940.4 \mathrm{~b}$ & $902.8 \mathrm{~b}$ \\
SE \pm & 101.7 & 42.31 & 76.15 \\
Significance & $* *$ & $* *$ & $* *$ \\
Interaction & & & NS \\
Tx E & NS & NS & \\
\hline
\end{tabular}

Keyword: Means within a column followed by same letter(s) are statistically similar $(\mathrm{P} \leq 0.05)$ using Duncan Multiple Range Test $($ DMRT); NS = Not Significance; PK-MN = Phosphorus + Potassium + Micronutrient; OM = Organic Manure; PK-MN-OM = Phosphorus + Potassium + Micronutrient + Organic Manure; PK $=$ Phosphorus + 


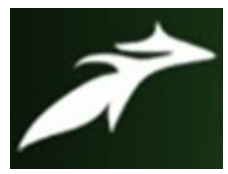

N.I Suleiman, International Journal of Advances in Agricultural Science and Technology,

Vol.8 Issue.2, February-2021, pg. 62-70

ISSN: 2348-1358

Impact Factor: 6.057

NAAS Rating: 3.77

Potassium; $\mathrm{CONTROL}=$ No input $\mathrm{P}=$ Phosphorus only; $\mathrm{T}=$ Treatment $\mathrm{E}=$ Experiment $* * *=$ significant at $1 \%$ Probability; WAS $=$ Weeks After Sowing.

\section{Days to Maturity}

Impact of biophysical conditions on the yield of legumes and varietal response to input of groundnut variety on days to maturity is presented in table 6. At Ajingi and the combined analysis all treatments under study produced statistically $(\mathrm{P} \leq 0.01)$ similar number of days to maturity. However, at Gaya site, application of PK-MN-OM, PKMN, OM, PK, P and the control produced statistically similar number of days to maturity, though the control and application of PK were statistically superior only to the application of PK-MN. In the combined analysis, all indicating no statistical difference among all treatments tested.

Table 6: Impact Of biophysical condition on the yield of legumes and varietal response to input of Groundnut Variety on Days to Maturity at Ajingi and Gaya and combined.

\begin{tabular}{lccc}
\hline Treatment & Ajingi & Gaya & Combined \\
\hline PK-MN-OM & 92.2 & $89.8 \mathrm{ab}$ & 91 \\
OM & 91.8 & $89.8 \mathrm{abc}$ & 90.8 \\
PK & 95.2 & $91.6 \mathrm{a}$ & 93.4 \\
P & 95.2 & $91.0 \mathrm{ab}$ & 93.1 \\
PK-MN & 94.4 & $90.2 \mathrm{bc}$ & 92.3 \\
CONTROL & 93.4 & $92.0 \mathrm{a}$ & 92.7 \\
SE \pm & 1.39 & 0.36 & 1.61 \\
Significance & $\mathrm{NS}$ & $* *$ & $\mathrm{NS}$ \\
Interaction & & & \\
Tx E & $\mathrm{NS}$ & $\mathrm{NS}$ & $\mathrm{NS}$ \\
\hline
\end{tabular}

Keyword: Means within a column followed by same letter(s) are statistically similar $(\mathrm{P} \leq 0.05)$ using Duncan Multiple Range Test $($ DMRT); NS = Not Significance; PK-MN = Phosphorus + Potassium + Micronutrient; OM = Organic Manure; PK-MN-OM = Phosphorus + Potassium + Micronutrient + Organic Manure; PK = Phosphorus + Potassium; $\mathrm{CONTROL}=$ No input; $\mathrm{P}=$ Phosphorus only; $\mathrm{T}=$ Treatment; $\mathrm{E}=$ Experiment $* * *=$ significant at $1 \%$ Probability; WAS= Weeks After Sowing.

\section{Conclusion}

Conclusively, the results of this study shown that, application of combination of PK-MN-OM and PK-MN were statistically superior only to the application of PK, P, OM and the control treatment.

\section{Recommendation}

From the finding of this study: it is hereby recommended that: -

- Application of PK-MN-OM and PK-MN should be adopted

- Organic manure at the rate of $40 \mathrm{~kg} / \mathrm{ha}$ should be use and combine with phosphorus fertilizer at the rate $30 \mathrm{~kg} / \mathrm{ha}$ which produced high yield

- Groundnut variety Samnut 24 is recommended 


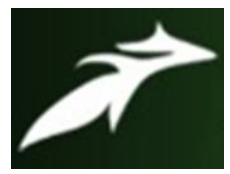

N.I Suleiman, International Journal of Advances in Agricultural Science and Technology, Vol.8 Issue.2, February-2021, pg. 62-70

ISSN: 2348-1358

Impact Factor: 6.057

NAAS Rating: 3.77

\section{References}

[1]. Adinya. I. B, Enun and Ijoma, J. U (2010).Exploring profitability potential Groundnut (Arachis hypogea L) production through Agro forestry practice. A case study of Nigeria Journal of Animal and Plant Science 20(2)2010 pp122-131.

[2]. Akobundu, E. (1998). Farm - Household Analysis of policies Affecting Groundnuts Production in senegal. Thesis submitted to the faculty of Virginia polytechnic.

[3]. Anonymous (2004). Raw Materials Research and Development Councils Survey of Agro Raw materials: groundnut pp96.

[4]. Bremner, J. M and Mulvaney C. S (1982). Nitrogen Total in methods of soil analysis, agronomy monograph No. 9 part 2, pp 595-624.

[5]. Busolo, W. W, Vander Merwe C.M (2002). Groundnut manual for Uganda: Recommended groundnut production practices for smallholder farmers in Uganda catham, UK: Natural Resouces Institute. ppl-2.

[6]. Ducan, D. B (1955). Multiple range and multiple F- Test. Biometrics 11: $1-42$.

[7]. Hong, N.X Mehan, V. K and M. T (1994). Status of groundnut batteries wilt in asia Proceedings of third working group meeting 4-5 july 1994 oil crop research institutes wuhan, china pp 135-141.

[8]. Nigam, S.N and Lenne, J.M (1996). Groundnut I ICRASAT Programmes. Grain Legumes No: 14- Sept, Oct, Nov. 1996 ICRASAT.

[9]. Pande, S. Bandypadhyay, R. Blummed, M. Narayana, T. Thomas, D. Navis, S.S (2003). Disease management factors influencing yield and quality of sorghum And groundnut crop residues. Field crops Res. 84. (1-2). Pp 89-103.

[10].Pompeu, A. S. (1980). Groundnut production, utilization, research problem and on Further research needs in Brazil proceeding of the international Workshopon Groundnuts. ICRASAT Center, Patancheru India 1317 October 1980.

[11].Romain, H. Raemaekers (2001). Crop production in the tropical Africa. Directorate General for international cooperation, Ministry of Foreign Affairs, external Trade and internal Cooperation Brussels, Belgium. 1540p.

[12].Sorrensen, R. Butts, C. Lamb, M. and Rowland, D. (2004). Five years of sub-surface drip Irrigate peanut, UGA/CPES RESEARCH and extension bulletin No: 2004.

[13].Snedecor G.W and Cochran W. G (1976).statistical methods applied to experiments in agriculture and biology. $5^{\text {th }}$ ed. Ames, Iowa State University Press, 1995.

[14].Teru, V. B. Kyanga, T. Z and Mshelia, S.T (2004). Profitability of groundnuts production in Michika Local Government Adamawa State Nigeria. Journal of Ag cultural Science. 1 (1): pp 25-29. 